\title{
Primjena geomorfoloških istraživanja u vojnoj analizi terena - indeks zaštitnog potencijala reljefa
}

\author{
Mladen Pahernik i Darko Kereša
}

\begin{abstract}
Primjena geomorfoloških istraživanja u vojnoj analizi reljefa, temeljena na GIS metodama prostorne analize, vezana je u prvom redu za vojno geografsku prosudbu prostora. Pri tom se podrazumijeva vrednovanje reljefa s obzirom na neposredni učinak, kako na premještanje snaga, manevar, preglednost, tako i na mogućnost zaštite i maskiranja. Provedena analiza vrednovanja zemljišta unutar dijela vojnog poligona «Slunj», uključila je definiranje boniteta kategorija reljefa s obzirom na mogućnost zaštite i prikrivanja u cilju uvrštavanja geomorfološke osnovice u standardnu vojnu proceduru OCOKA(Observation and fields of fires; Cover and concealment; Obstacles and movement; Key terrain; Avenus of approach). Definirani model prostorne analize terena uključio je pet parametara reljefa (vidljivost, konkavne elemente reljefa, ekspoziciju padina, gustoću ponikava i dolina unutar jedinične površine) koji u znatnoj mjeri utječu na mogućnost zaštite i prikrivanja. Morfometrijski podaci uključeni u pojedine bonitetne kategorije određeni su temeljem analize digitalnog modela reljefa primjenom GIS alata i postavljenih morfometrijskih metoda istraživanja reljefa. Na temelju postavljenog modela izračunati su parametri i izrađena je karta potencijalne zaštite i prikrivenosti, unutar pilot područja vojnog poligona «Slunj».

Ključne riječi: GIS metoda, vojna geografija, morfometrija, digitalni model reljefa, geomorfološka istraživanja, Slunj
\end{abstract}

\section{Geomorphology Exploration Applies in Military Terrain Analyses -Index of Protective Potential Relief}

Geomorphology exploration applies in military terrain analyses is based on GIS methodology of spatial analyses and related on first place with military therein analysis. In that is included relief assessment related with close effect, how on force displacement, maneuver and clearness so as on cover and concealment. Executed analyses of land assessment, on part of military training area "Slunj", was include defining of estimate relief categories in relation with cover and concealment in aim to put into a group geomorphology bases in standard military procedure OCOKA (Observation and fields of fires; Cover and concealment; Obstacles and movement; Key terrain; Avenues of approach). Defined model spatial therein analyses was include five parameters of relief (visibility, hollow relief elements, slope exposition, funnel-shaped hole in limestone formation and valley density inside of unit surface) which in most usual cases relate on cover and concealment. Morphometric data's included in partial assessment categories were determine on base of analyses digital model relief, and by using GIS tools and placed Morphometric relief exploration methods.

On base of sated model, were calculated parameters, and produced was map of potential cover and concealment inside of pilot area in military training area "Slunj".

Key words: GIS method, military geography, morphometry, digital model of relief, geomorphologic researches, Slunj 


\section{UVOD}

Zemljište čini prirodni dio bojišnice, te je za njegovu učinkovitu uporabu u borbenim operacijama od ključne važnosti geografska analiza prostora. Bojišnica uključuje područje odgovornosti dodijeljeno postrojbi, okolno zemljište koje može utjecati na operacije i zračni prostor izravno iznad njega. Razumijevanje ograničenja i mogućnosti zemljišta predstavlja dio vojnog umijeća, a detaljnost analize ovisi o razini vojnog zapovijedanja. Proučavanje zemljišta obavlja se temeljem zadaća postrojbi kroz definiranje potencijala zemljišta za zaklanjanje i prikrivanje, njegov utjecaj na vlastitu pokretljivost i pokretljivost protivnika, te njegovo korištenje za promatranje i učinke izravne paljbe. Na temelju spomenutih analiza potrebno je doći do rezultata o povoljnim i negativnim aspektima zemljišta unutar dane vojne zadaće, a s ciljem donošenja odluke o učinkovitoj uporabi vlastitih snaga. Pri tomu se teži zaštititi vlastite snage, a protivnika dovesti u nepovoljan položaj. Detaljna analiza zemljišta, kroz provedenu sintezu spomenutih temeljnih vojnih čimbenika zemljišta mora osigurati prosudbu opće organizacije zemljišta i njegove značajke, glavne smjerove kretanja uključujući i prilaze iz zraka na malim visinama, te definiranje ključnog zemljišta unutar prostora dodijeljenog postrojbi. To zemljište predstavlja dominantne dijelove zemljišta koji su od iznimne važnosti za provedbu dobivene zadaće i predstavljaju ključno područje interesa, odnosno usredotočenje napadnih odnosno obrambenih napora dotične postrojbe.

Zemljište može zaštititi postrojbu od protivničke paljbe ili može prikriti snage od promatranja. Prikrivanje snaga koje izvode manevar može predstavljati veliku taktičku prednost. Branitelji to mogu iskoristiti kako bi protivnika navukli u duboko pripremljena obrambena područja, dok napadači prikrivanje koriste kako bi izbjegli otkrivanje ili napad dok prilaze branjenim područjima. Suvremene metode vojnih analiza zemljišta bazirane su prvenstveno na prostornim bazama podataka i analizama koje uključuju čitav niz algoritama automatizirane analize terena. One su, u prvom redu vezane za procedure obavještajne pripreme bojnog polja (Grindle et al. 2004), te unutar njih za analize vojnih aspekata zemljišta. Pri tome se koriste različite tehnologije prostorne analize, uključujući geografske informacijske sustave, daljinska istraživanja i globalni sustav pozicioniranja (GPS). Zbog što realnije simulacije analiziranog zemljišta koristi se metoda višekriterijskih analiza (Friend 2005), pri čemu se izdvajaju pojedini parametri zemljišta, kvalificiraju s obzirom na utjecaj na promatranu pojavu, te završnom sintezom prikazuju u vidu tematskih karata.

U radu se razmatra učinak parametara reljefa, kao temeljne komponente ukupnog indeksa zaštitnog potencijala zemljišta u koju između ostalog ulaze i prostorni raspored i obilježja visoke vegetacije, te gustoća i veličina naselja, a koja zbog obima rada nisu detaljno analizirana. Glavni izvor informacija za analize koje uključuju reljef, kao jedan od temeljnih elemenata vojne analize zemljišta je digitalni model reljefa (DMR). Primjena parametara reljefa izračunatih na temelju DMR-a ovisit će o njegovoj rezoluciji, pri čemu se naglasak daje na analizi DMR-a visoke rezolucije (Guth, 2005). Drugi problem vezan za primjenu DMR-a u pojedinim vojnim analizama zemljišta, npr. provjeri optičke vidljivosti u prostoru, odnosi se na prikaz visinskih atributa vegetacije i naseljenih područja (zgrada) u sam visinski model, pri čemu on de facto postaje digitalni model terena. (Guth 2005). Parametri računani pomoću DMR uključeni su u različite algoritme mobilnosti (Cesur 
2005), kao što su: NRMM II - NATO reference mobility model edition II, (Ahlvin and Haley 1992), ModSAF -The Modular Semi-Automated Forces, (Birkel 2003), analize optičke vidljivosti (Salomon et al. 2004), te geoekološke analize zemljišta ugroženog učestalom uporabom terenskih vozila (Johnson and Smith 1983, Patricia et al. 2000).

Poligon «Slunj» vojni je poligon multifunkcionalne namjene koji se nalazi $3 \mathrm{~km}$ zapadno od grada Slunja. Ovim radom obuhvaćeno je područje SZ dijela vojnog poligona, između rijeke Mrežnice na sjeveroistoku i gorskog hrpta Hum (861m) na zapadu, površine $58 \mathrm{~km}^{2}$ (Sl. 1).

Prema geomorfološkoj regionalizaciji Hrvatske (Bognar 2001.) istraživani prostor nalazi se na kontaktu mezomorfoloških regija Unsko - Koranske zaravni na JI, i gorskobrdskog okvira Ogulinsko - Plaščanske zavale na SZ. Različitost u reljefnim oblicima istraživanog područja s dijelovima zaravni, pobrđa i gorskih masiva na relativno malom prostoru pogoduje osnovnoj namjeni rada, geomorfološkoj bonifikaciji reljefa s obzirom na mogućnost vojno-geografske analize zaštite i prikrivanja.

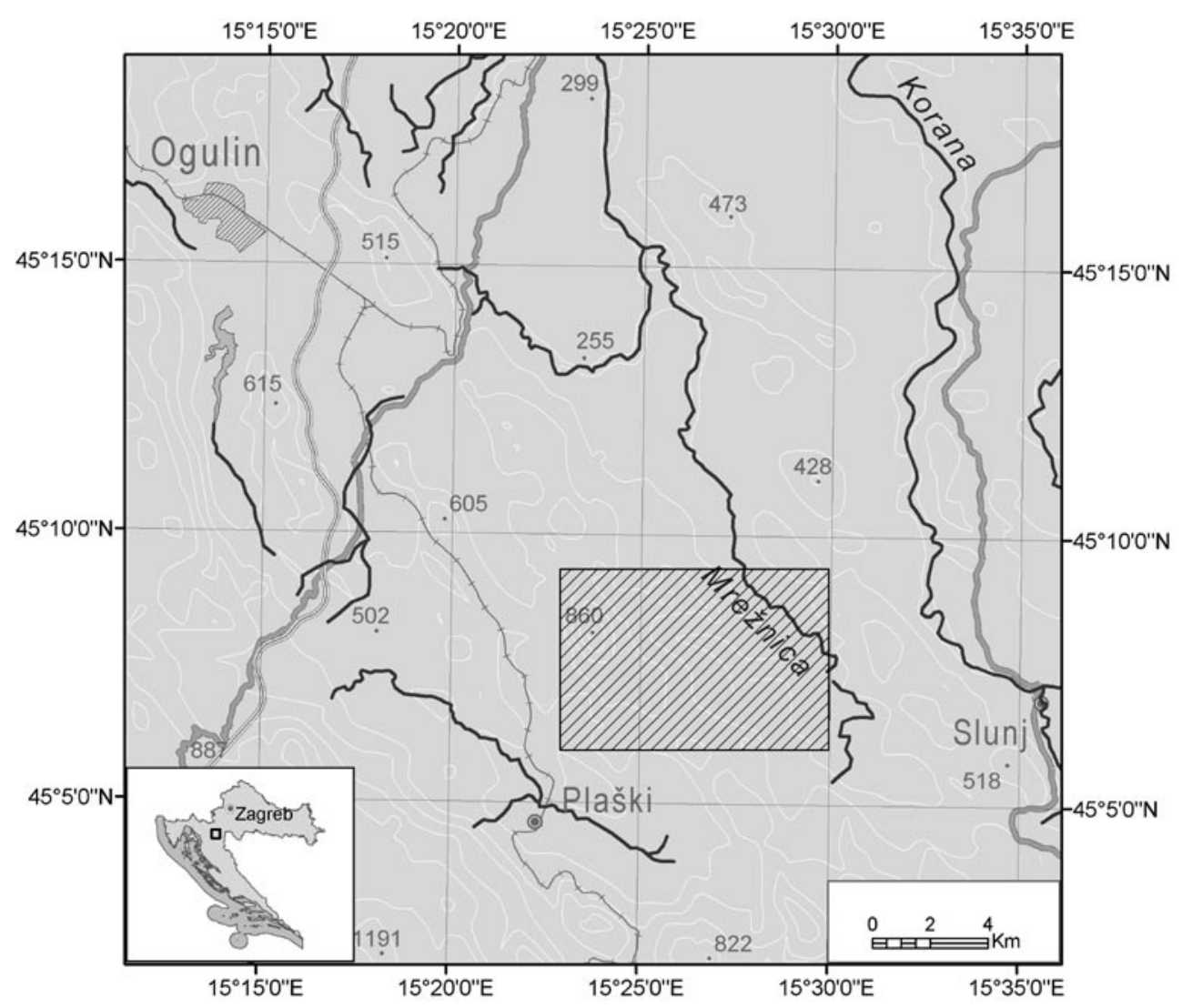

S1. 1. Geografski položaj istraživanog područja

Fig. 1. Geographic position of the researched area 
Geografsko informacijski sustav predstavlja, u najužem smislu računalni alat za modeliranje i analiziranje geografskih objekata odnosno pojava i događaja u prostoru. Modeliranje digitalnih geografskih podataka pomoću GIS tehnologije omogućuje bolju razmjenu i uporabu prostornih podataka između različitih vojnih struktura koje ih koriste. Indeks zaštitnog potencijala reljefa temeljen je na integraciji parametara geomorfoloških i standardiziranih vojnih analiza reljefa provedenog pomoću GIS-a.

\section{ČIMBENICI ZAŠTITNOG POTENCIJALA RELJEFA}

Na mogućnost zaštite i prikrivanja utječe čitav niz čimbenika, od reljefnih obilježja $\mathrm{u}$ vidu orografije, ekspozicije padina u odnosu na vlastite i protivničke strane, rasporeda i pružanja pojedinih konkavnih elemenata reljefa kao što su duboko usječene riječne doline ili uvale te veće ponikve u prostoru krša, preko naseljenih zona, prostornog rasporeda i vrste šumske vegetacije do trenutnih vremenskih uvjeta u promatranom prostoru. Grupiramo li nabrojane čimbenike prema njihovoj stalnosti, odnosno nepromjenjivosti, bilo u prostornoj ili vremenskoj domeni, slijedi da su parametri reljefa vezani za grupu postojanih čimbenika, vegetacijski za grupu sezonski promjenjivih, a vremenski za učestalo promjenjive čimbenike. Zbog velikog utjecaja reljefnih obilježja na mogućnost zaštite i prikrivanja, te stalnosti tih parametara u radu će se detaljno analizirati morfometrijska obilježja reljefa vezana za orografiju, ekspoziciju padina, te prostorni raspored pojedinih konkavnih reljefnih oblika.

Gledajući s aspekta reljefa, vidljivost s pojedine točke ovisi primarno o orografskim obilježjima prostora, a sekundarno o nadmorskoj visini same točke. Pri tom se misli na prostorni položaj točke vezano uz oblik reljefa na kojem se nalazi, te orografsku strukturu okolnog, promatranog prostora. Sa strane mogućnosti zaštite i maskiranja bonitete kategorije reljefa definirane su vrijednostima ukupnog broja dominantnih točaka prostora (potencijalnih motrišta) vidljivih iz pojedine točke promatranog prostora. Tako će se iz dna uvale vidjeti samo nekoliko, a sa prostrane zaravni većina potencijalnih motrišta. Pojednostavljena metoda određivanja kategorija vidljivosti zemljišta na primjeru triju motrišta prikazana je na slici 2. Činjenica da vrijedi i obrnuti smjer vidljivosti, odnosno da će dno uvale biti vidljivo sa samo par dominantnih točaka - motrišta, uzeta je za osnovu prilikom bonifikacije zemljišta s obzirom na orografsku strukturu - analizu vidljivosti.

Za vrednovanje mogućnosti zaštite i prikrivenosti od velikog značaja su prostorni raspored i morfometrijska obilježja konkavnih oblika reljefa, pod kojima se podrazumijevaju sva udubljena bez obzira na morfogenetski tip. Kako je istraživani prostor vezan za krš, unutar njega nalazimo veći broj različitih uvala i ponikava, uz različite konkavne forme derazijskog porijekla u vidu della i derazijskih dolina, te dominantna linijska udubljenja duboko usječenih riječnih dolina - sutjeska i kanjona.

Uloga orijentiranosti padina u odnosu na strane svijeta, prilikom analiza zaštite i prikrivenosti, značajna je samo u slučaju kada nam je poznata tzv. taktička orijentacija koja uključuje poznavanje rasporeda naših u odnosu na protivničke snage. Definiranjem položaja protivnika u odnosu na naše položaje jasno se određuju padine koje su otvorene, zaklonjene ili okrenute bočno u odnosu na snage protivnika. 

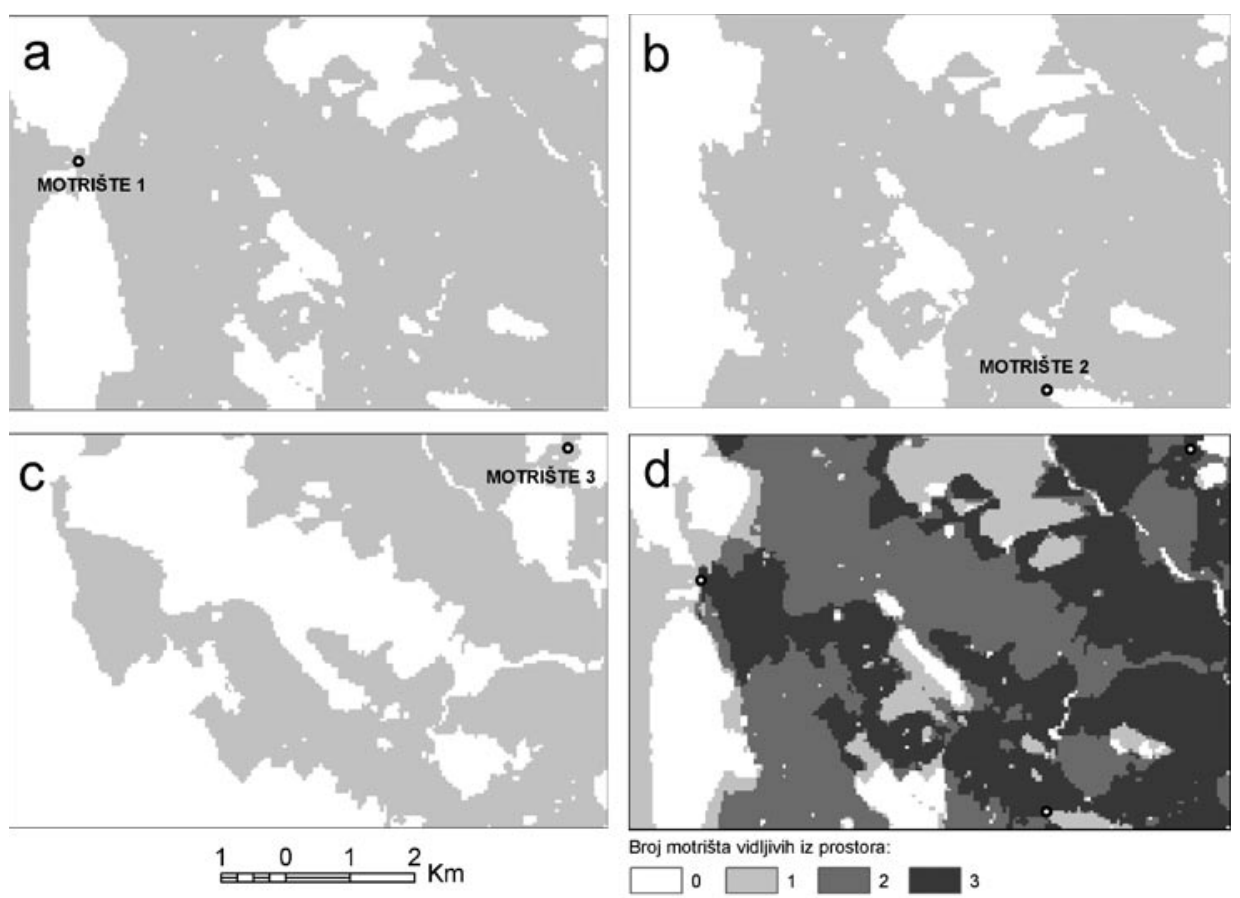

S1. 2. Metoda određivanja kategorija vidljivosti zemljišta; $a-c$ pojedinačne analize vidljivosti s motrišta; $\mathrm{d}$-vrijednosti zbroja ćelija koja predstavljaju vidljiv prostor s pojedinog motrišta pri čemu 0 predstavlja prostor koji nije vidljiv niti sa jednog motrišta, a 3 prostor koji je vidljiv iz svih motrišta.

Fig. 2. Method of determination of land visibility categories; a-c individual analyses of visibility from a standpoint; $d$-cell sum values which represent the area visible from particular standpoints, where " 0 " stands for the area visible from no standpoints, and 3 for the area visible from all standpoints

Dosad opisani parametri predstavljaju temelj analize mogućnosti zaštite i prikrivanja, te su svrstani u grupu primarnih čimbenika. Kao modifikacijski parametri, definirani kao sekundarni čimbenici javljaju se prostorne gustoće pojedinih reljefnih oblika značajnih za mogućnost zaštite i maskiranja kao što su gustoća ponikava, te dolinska mreža. Pod dolinskom mrežom podrazumijevaju se sve vrste dolinskih oblika, bez obzira na morfogenetsko porijeklo (fluvijalni, derazijski, fluviokrški i krški dolinski oblici).

\section{METODA INDEKSA ZAŠTITNOG POTENCIJALA RELJEFA}

Na temelju definiranih čimbenika zaštitnog potencijala reljefa vezanih za prostor vojnog poligona «Slunj» određeni su ulazni parametri modela, te metode njihovog računanja. Većina parametra definirana je na temelju analize digitalnog modela reljefa (konkavni oblici reljefa, vidljivost, ekspozicija padina, gustoća dolinskih oblika), odnosno vektorizacijom položaja ponikava i motrišta s topografskih karata i aerofotosnimaka. U radu je korišten digitalni model reljefa GRID formata, rezolucije 10 metara kreiran na 
Hrvatski geografski glasnik 69/1 (2007.)
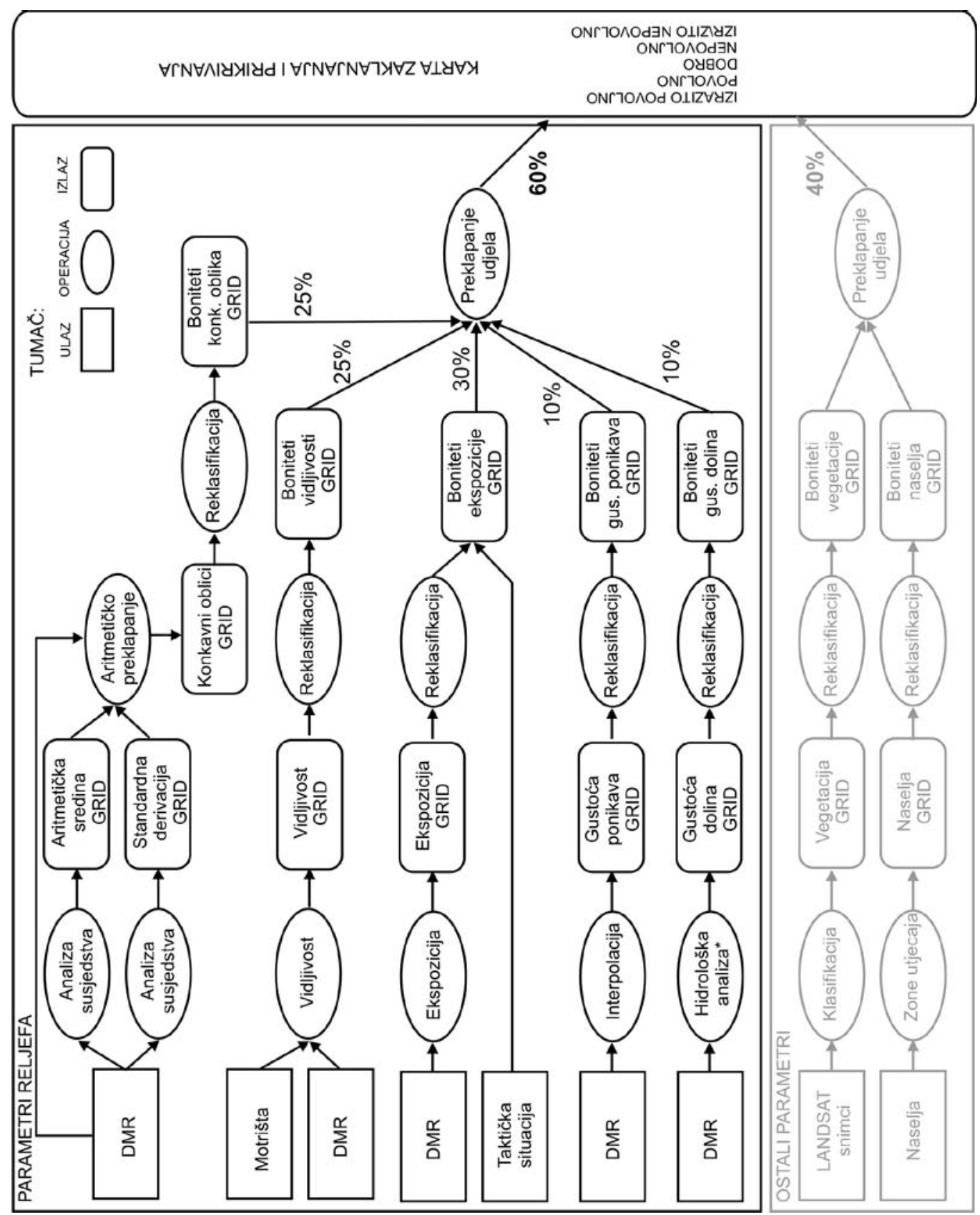

S1. 3. Model indeksa zaštitnog potencijala zemljišta s izdvojenim parametrima reljefa (ostali parametri prikazani sivom nijansom nisu analizirani u radu)

Fig. 3. Model of the land protection potential with the singled out relief parameters (other parameters presented by grey colour have not been analyzed in this paper) 
temelju izohipsa TK 25 000, ekvidistance 10 metara. Za GIS analize uporabljen je softver ArcGIS 9.0 sa ekstenzijom Spatial Analyst. Unutar prve faze modela svi ulazni podaci pretvaraju se u rasterski GRID format, kako bi se u završnoj fazi, primjenom metoda rasterske algebre mogli prostorno analizirati (Sl. 3).

Analiza vidljivosti u funkciji mogućnosti prikrivanja započinje definiranjem potencijalnih motrišta - dominantnih vrhova u prostoru. Prosječna gustoća odabranih motrišta ovisi o površini i orografskoj strukturi analiziranog prostora, pri čemu se analizom broja motrišta u različitim reljefnim orografskim cjelinama došlo do optimalne vrijednosti od cca. 30 točaka na $50 \mathrm{~km}^{2}$. Tako je u istraživanom prostoru definirano 28 dominantnih vrhova s kojih je provedena analiza optičke vidljivosti okolnog prostora. Izračunat je novi rasterski GRID sloj čija vrijednost pojedine ćelije definira broj vrhova (potencijalnih motrišta) s kojih je ta točka (ćelija) vidljiva. Tako svaka ćelija može teoretski poprimiti vrijednost između 0 (točka nije vidljiva niti sa jednog motrišta) i 28 (točka je vidljiva sa svih motrišta). Analiza vidljivosti provedena je algoritmom Visibility ArcGIS programskog paketa, a izračunate vrijednosti prikazane su na slici 4 .

Definiranje konveksnih reljefnih oblika pomoću digitalnog modela reljefa određena je metodom računanja standardiziranog obilježja visina unutar kvadrata definirane površine (Pahernik, 2005). Vrijednost standardiziranog obilježja visina $(\sigma)$ predstavlja odstupanje

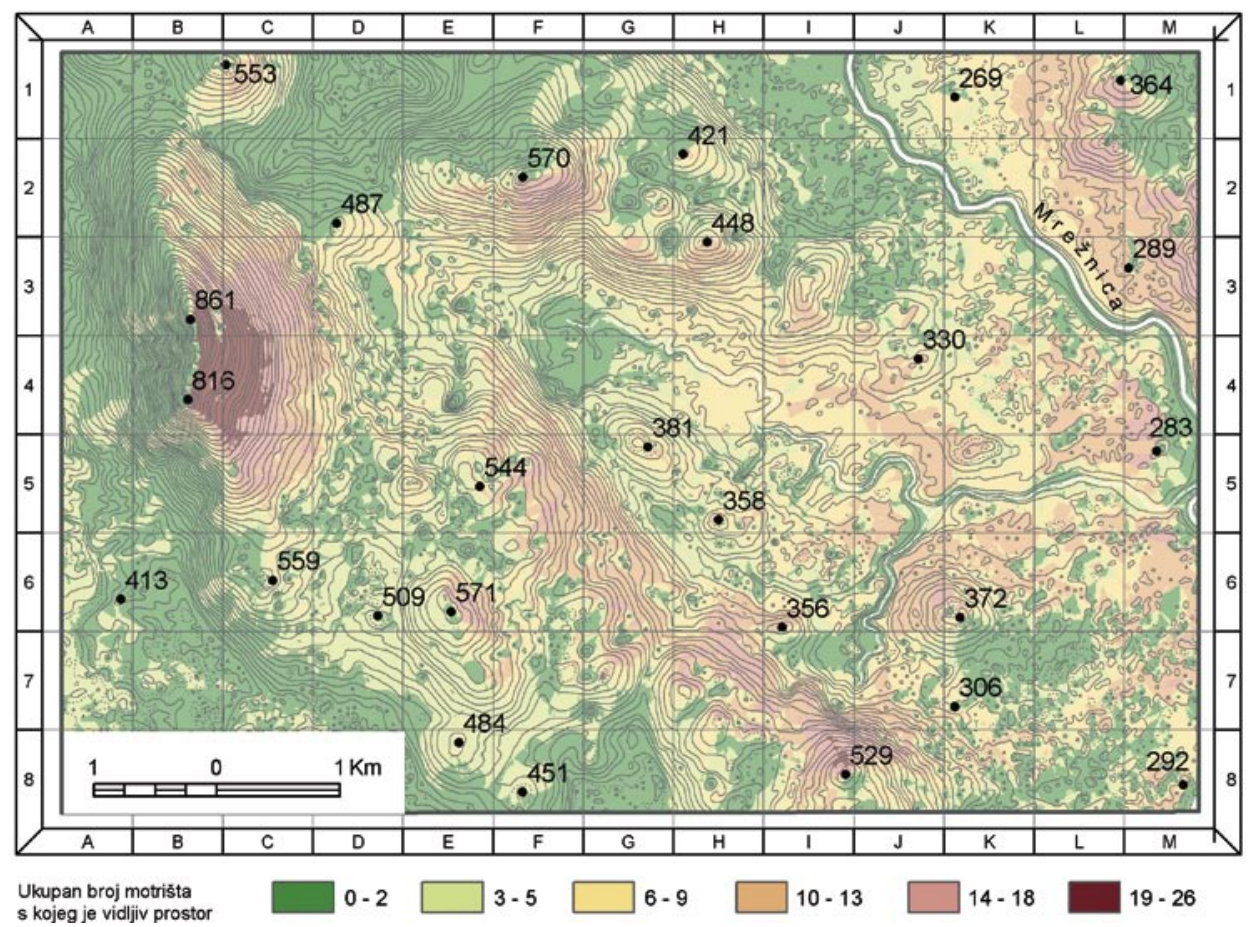

S1. 4. Vrijednosti analize vidljivosti s dominantnih vrhova (motrišta)

Fig. 4. Analysis values of visibility from dominant summits (standpoints) 
visine pojedine ćelije GRID-a od aritmetičke sredine visina unutar jedinične površine, izražene u jedinicama standardne devijacije:

$$
\sigma=\sqrt{\left(\frac{1}{n_{c}-1} \sum_{i \in c}\left(h_{i}-\bar{h}\right)^{2}\right)}
$$

gdje je,

$n_{c}$ - ukupan broj vrijednosti visina unutar definirane jedinične površine

$h_{i}$ - visina pojedine ćelije definirane jedinične površine

$\bar{h}$ - aritmetička sredina visina unutar definirane jedinične površine

Atribut standardiziranog obilježja visine predstavlja mjeru relativne topografske pozicije kao dijela lokalnog reljefa i kao takav određen je intenzitetom visinskih promjena reljefa. Najveća koncentracija vrijednosti ovog atributa je u rasponu od $-0,1$ do 0,1 a te vrijednosti predstavljaju površine bez izrazite konkavnosti odnosno konveksnosti. Vrijednosti većeg negativnog predznaka označavaju izrazito konkavne reljefne oblike dok pozitivne vrijednosti definiraju izrazito konveksne oblike. Na slici 5 prikazane su vrijednosti standardiziranog obilježja definirane kao konveksni, konkavni i reljefni oblici bez izrazite zakrivljenosti (zaravni i uravnotežene padine).

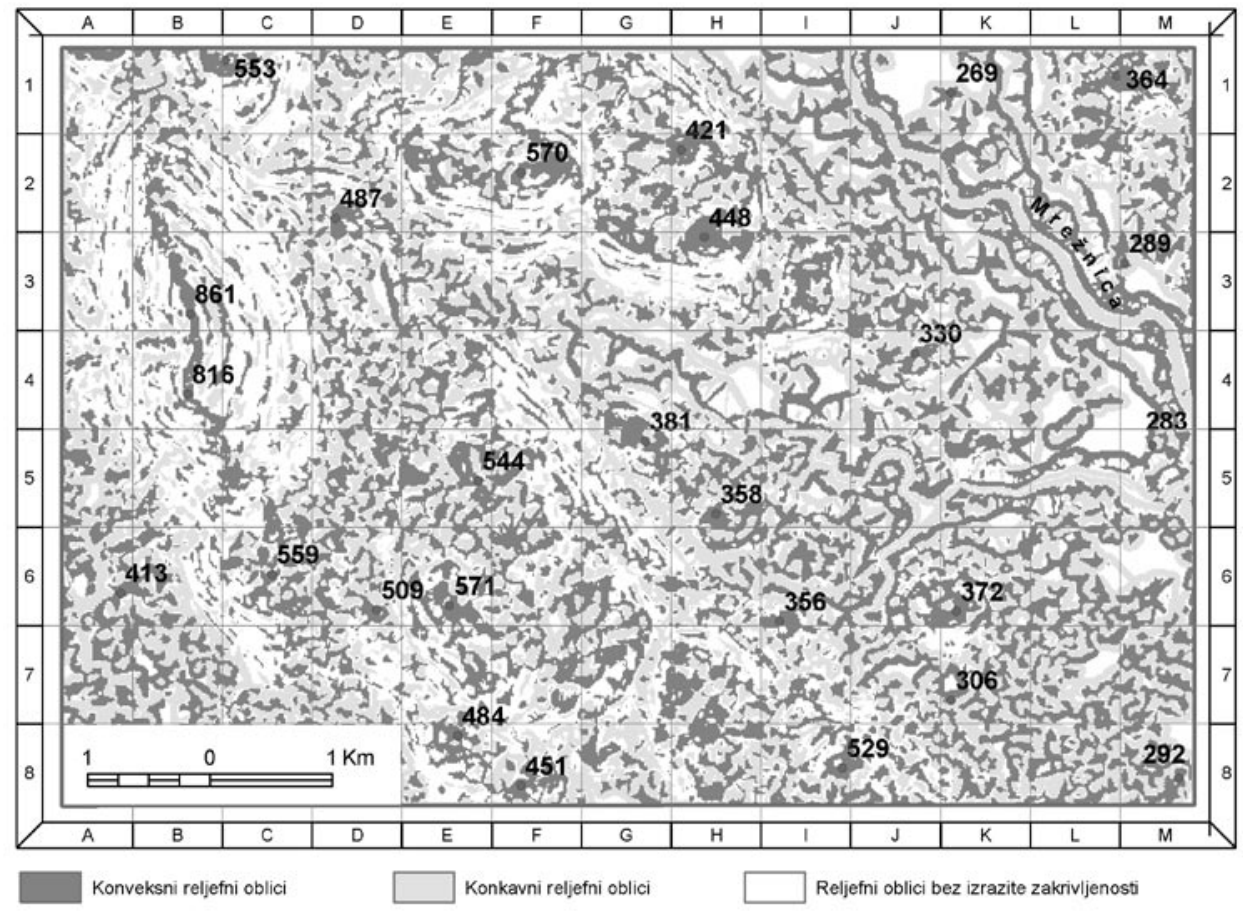

Sl. 5. Konkavni oblici reljefa

Fig. 5. Concave reliefforms 


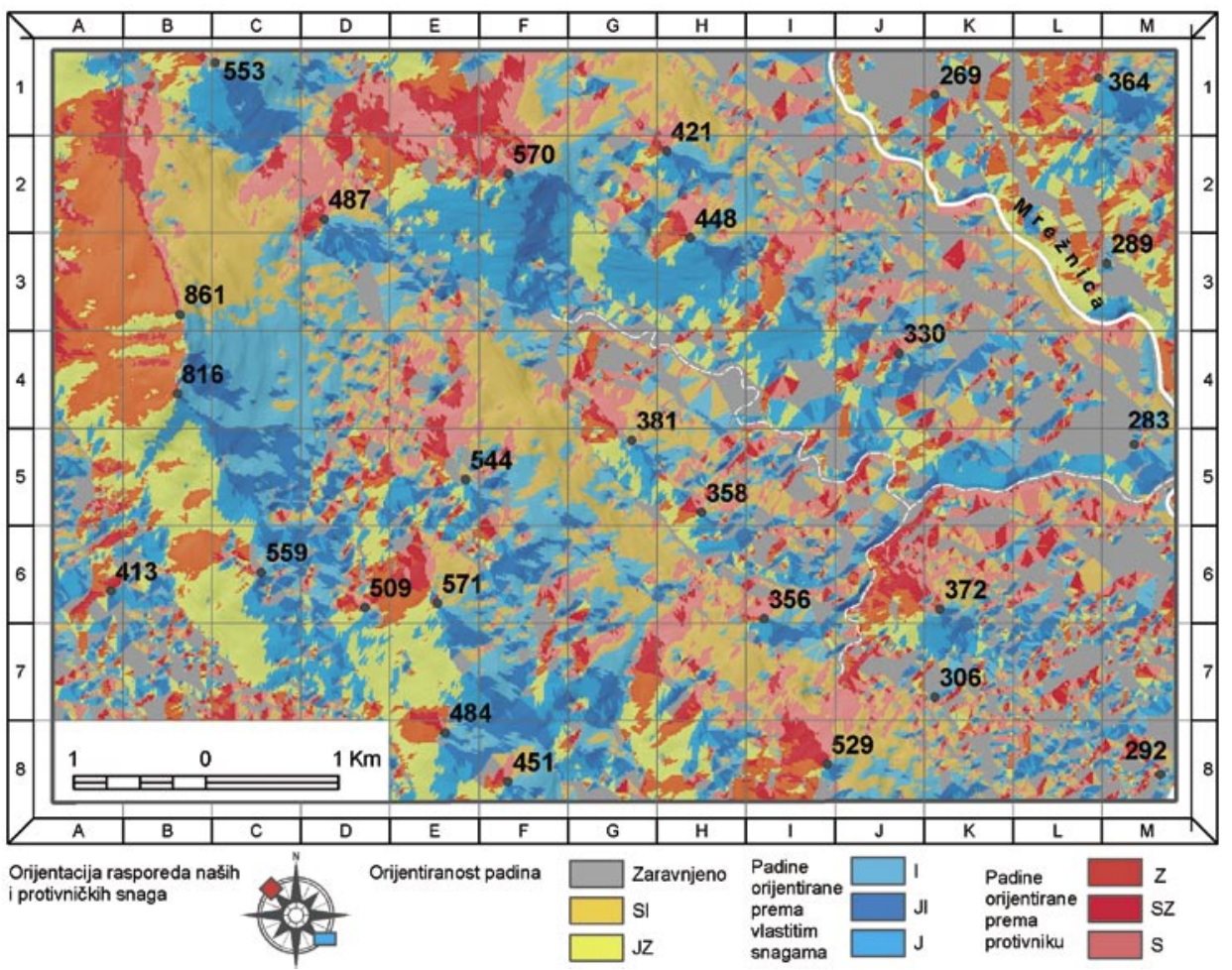

S1. 6. Orijentacija padina s obzirom na vlastite i protivničke snage

Fig. 6. Orientation of slopes regarding their own and antagonistic forces

Izračunom ekspozicije na temelju digitalnog modela reljefa unutar ArcGIS programskog paketa određene su vrijednosti ekspozicija padina istraživanog područja prema rasponu azimuta glavnih i pomoćnih strana svijeta. Kako bi se mogla odrediti bonitetna vrijednost pojedinih ekspozicija padina definiran je položaj protivničkih i vlastitih snaga, gdje su snage protivnika smještene u smjeru sjeverozapada, a vlastite u smjeru jugoistoka (Sl. 6).

Digitalizacijom dna ponikava na temelju digitaliziranih topografskih karata mjerila $1: 25000$, te aerofotosnimaka približnog mjerila $1: 22000$ načinjen je točkasti sloj ponikava, gdje svaka točka predstavlja dno jedne ponikve. Primjenom kernelovog algoritma određivanja prostorne gustoće točkastih objekata, bazirane na kvadratnoj kernelovoj funkciji (Silverman 1986) izračunat je ukupan broj jedinica unutar jedinične površine od $1 \mathrm{~km}^{2}$ (Slika 7). Kernelova gustoća računa broj promatranih jedinica unutar definiranog susjedstva (jedinične površine) oko tih objekata. Vrijednosti gustoće ponikava definirane su kao atribut za svaku pojedinu središnju ćeliju jedinične površine novog rastera.

Određivanje dolinske mreže za potrebe definiranja njihove gustoće unutar jedinične površine definirano je primjenom metode primarnog smjera otjecanja (Primary flow direction - FLOWD), koja određuje smjer otjecanja niz padinu analizom susjednih ćelija sa maksimalnim gradijentom pada (Jenson and Domingue 1988). Vrijednosti smjera otjecanja, površine akumulacija, te sama dolinska mreža u vektorskom formatu podataka 


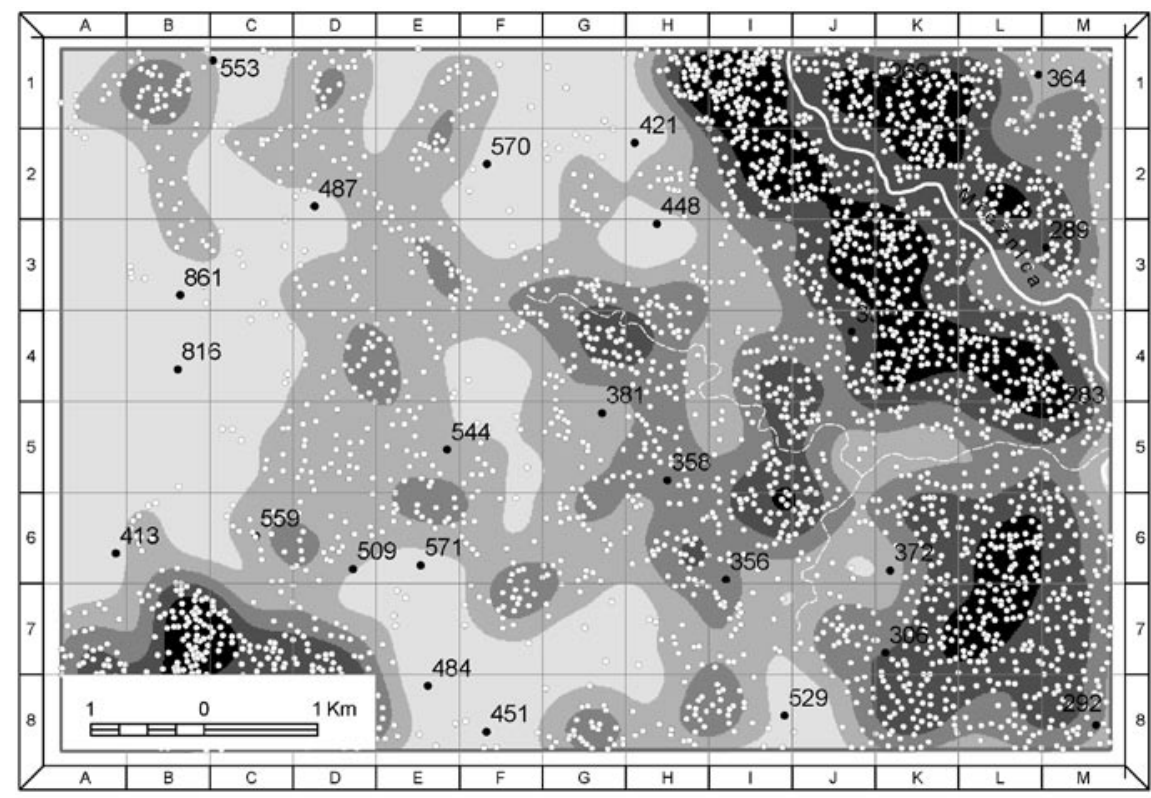

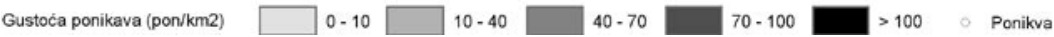

S1. 7. Gustoća ponikava

Fig. 7. Density of dolines

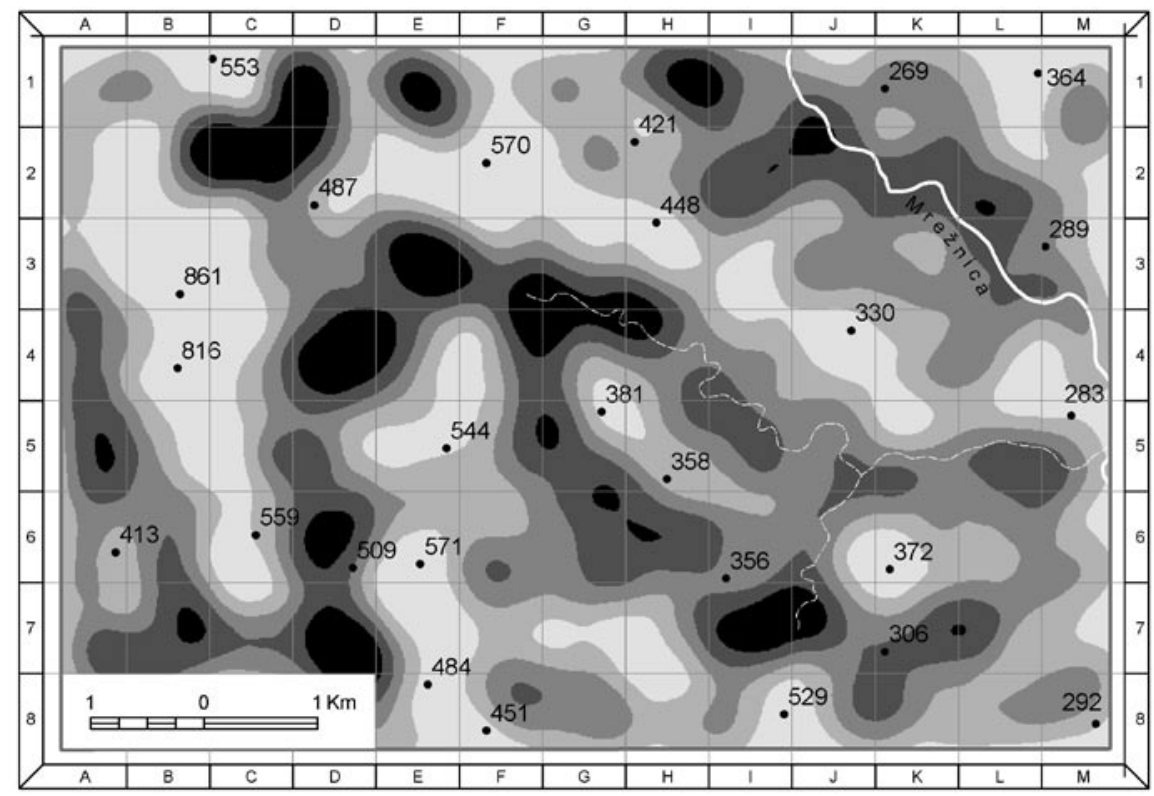

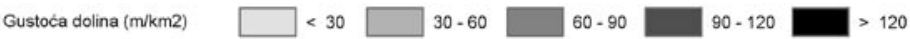

S1. 8. Gustoća dolinske mreže

Fig. 8. Density of doline network 
(S1. 8) izračunate su pomoću algoritma hidrogeološke funkcije unutar ArcGIS ekstenzije Spatial Analyst. Prilikom računanja gustoće dolinske mreže također je primijenjen kernelov algoritam, a izračunate vrijednosti predstavljaju gustoću dolinske mreže u pojedinoj ćeliji GRID-a unutar definirane površine od $1 \mathrm{~km}^{2} \mathrm{u}$ čijem središtu se sama ćelija i nalazi.

Nakon definiranja vrijednosti zaštitnih parametra reljefa, te njihovog prikaza u rasterskom GRID formatu definirani su razredi vrijednosti zaštitnog potencijala u rasponu od 1 do 5 za primarne varijable, te raspon od 0 do 2 za sekundarne varijable (Tablica 1). Nakon reklasifikacije ${ }^{1}$ vrijednosti klasa u nove bonitetne kategorije slijedi primjena metode rasterske algebre - težinsko preklapanje udjela. Pomoću ove metode prostorne analize moguće je definirati intenzitet ulaznih vrijednosti udjela pojedinog sloja u konačnom rezultatu. Definirani utjecaj iskazuje se najčešće kroz postotak, pri čemu je najveći problem upravo definiranje intenziteta utjecaja pojedinog parametra analize u ukupnom rezultatu. Dok je

Tab. 1. Parametri indeksa zaštitnog potencijala reljefa

\begin{tabular}{|c|c|c|c|c|c|}
\hline $\mathrm{Rb}$ & Varijable & Klase & Opis klase & $\begin{array}{c}\text { Boni- } \\
\text { tet }\end{array}$ & Zaštita \\
\hline 1. & Vidljivost & $\begin{array}{l}>23 \text { točaka vidljivo } \\
17-22 \text { točaka vidljivo } \\
12-17 \text { točaka vidljivo } \\
6-11 \text { točaka vidljivo } \\
<5 \text { točaka vidljivo }\end{array}$ & $\begin{array}{l}\text { - Izrazito otvoren prostor } \\
\text { - Otvoren prostor } \\
\text { - Zaštićen prostor } \\
\text { - Dobro zaštićen prostor } \\
\text { - Izrazito zaštićen prostor }\end{array}$ & $\begin{array}{l}1 \\
2 \\
3 \\
4 \\
5\end{array}$ & $\begin{array}{l}\text { - Izrazito nepovoljna } \\
\text { - Nepovoljna } \\
\text { - Dobra } \\
\text { - Povoljna } \\
\text { - Izrazito povoljna }\end{array}$ \\
\hline 2. & $\begin{array}{l}\text { Konkavni } \\
\text { oblici } \\
\text { reljefa }\end{array}$ & $\begin{array}{l}<-2 \mathrm{StDev} \\
-1 \mathrm{StDev} \\
0 \mathrm{StDev} \\
1 \mathrm{StDev} \\
>2 \mathrm{StDev} \\
\end{array}$ & $\begin{array}{l}\text { - Izrazito konveksni oblici } \\
\text { - Konveksni oblici } \\
\text { - Zaravni } \\
\text { - Konkavni oblici } \\
\text { - Izrazito konkavni oblici }\end{array}$ & $\begin{array}{l}1 \\
2 \\
2 \\
4 \\
5\end{array}$ & $\begin{array}{l}\text { - Izrazito nepovoljna } \\
\text { - Nepovoljna } \\
\text { - Nepovoljna } \\
\text { - Povoljna } \\
\text { - Izrazito povoljna }\end{array}$ \\
\hline 3. & $\begin{array}{l}\text { Ekspo- } \\
\text { zicija } \\
\text { padine }\end{array}$ & $\begin{array}{l}\text { Sjeverozapad } \\
\text { Zapad, sjever } \\
\text { Jugoistok } \\
\text { Jug, Istok } \\
\text { Sjeveroistok, } \\
\text { Sjeverozapad }\end{array}$ & $\begin{array}{l}\text { - Padine direktno okrenute } \\
\text { protivniku } \\
\text { - Padine bočno okrenute } \\
\text { protivniku } \\
\text {-Padine okrenute vlastitim } \\
\text { snagama } \\
\text { - Padine bočno okrenute } \\
\text { vlastitim snagama } \\
\text { - Bočno okrenute padine }\end{array}$ & $\begin{array}{l}1 \\
2 \\
5 \\
4 \\
3 \\
2\end{array}$ & $\begin{array}{l}\text { - Izrazito nepovoljna } \\
\text { - Nepovoljna } \\
\text { - Izrazito povoljna } \\
\text { - Povoljna } \\
\text { - Dobra } \\
\text { - Nepovoljna }\end{array}$ \\
\hline 4. & $\begin{array}{l}\text { Gustoća } \\
\text { dolinske } \\
\text { mreže }\end{array}$ & $\begin{array}{l}<30 \mathrm{~m} / \mathrm{km}^{2} \\
30-60 \mathrm{~m} / \mathrm{km}^{2} \\
60-90 \mathrm{~m} / \mathrm{km}^{2} \\
90-120 \mathrm{~m} / \mathrm{km}^{2} \\
>120 \mathrm{~m} / \mathrm{km}^{2} \\
\end{array}$ & $\begin{array}{l}\text { - Neznatna gustoća } \\
\text { - Mala gustoća } \\
\text { - Srednja gustoća } \\
\text { - Velika gustoća } \\
\text { - Vrlo velika gustoća }\end{array}$ & $\begin{array}{c}0 \\
0,5 \\
1 \\
1,5 \\
2\end{array}$ & $\begin{array}{l}\text { - Izrazito nepovoljna } \\
\text { - Nepovoljna } \\
\text { - Dobra } \\
\text { - Povoljna } \\
\text { - Izrazito povoljna }\end{array}$ \\
\hline 5. & $\begin{array}{l}\text { Gustoća } \\
\text { ponikava }\end{array}$ & \begin{tabular}{|l|}
$<10$ ponikava $\mathrm{km}^{2}$ \\
$10-40$ ponikava $\mathrm{km}^{2}$ \\
$40-70$ ponikava $\mathrm{km}^{2}$ \\
$70-100$ ponikava \\
$\mathrm{km}^{2}$ \\
$>100$ ponikava $\mathrm{km}^{2}$ \\
\end{tabular} & $\begin{array}{l}\text { - Neznatna gustoća } \\
\text { - Mala gustoća } \\
\text { - Srednja gustoća } \\
\text { - Velika gustoća } \\
\text { - Vrlo velika gustoća }\end{array}$ & $\begin{array}{l}0 \\
0,5 \\
1 \\
1,5 \\
2\end{array}$ & $\begin{array}{l}\text { - Izrazito nepovoljna } \\
\text { - Nepovoljna } \\
\text { - Dobra } \\
\text { - Povoljna } \\
\text { - Izrazito povoljna }\end{array}$ \\
\hline
\end{tabular}


Tab. 2. Korelacijska matrica parametara modela Indeksa zaštitnog potencijala zemljišta

\begin{tabular}{|l|c|c|c|c|c|}
\hline & vidljivost & konkavnost & orijentiranost & ponikve & doline \\
\hline vidljivost & 1,00 & $-0,20$ & $-0,05$ & 0,02 & 0,21 \\
\hline konkavnost & $-0,20$ & 1,00 & 0,04 & $-0,02$ & $-0,08$ \\
\hline orijentiranost padina & $-0,05$ & 0,04 & 1,00 & $-0,24$ & $-0,06$ \\
\hline gustoća ponikava & 0,02 & $-0,02$ & $-0,24$ & 1,00 & 0,27 \\
\hline gustoća dolina & 0,21 & $-0,08$ & $-0,06$ & 0,27 & 1,00 \\
\hline suma & 0,98 & 0,74 & 0,69 & 1,03 & 1,34 \\
\hline$\%($ sume $)$ & 21 & 15 & 14 & 22 & 28 \\
\hline
\end{tabular}

najjednostavniji način određivanja intenziteta utjecaja pojedinog parametara na ukupan rezultat vezan za aproksimativnu procjenu na temelju iskustva, u radu je postotni udio pojedine varijable definiran temeljem korelacijske matrice svih parametra analize (Tabl. 2).

Zbrajanjem koeficijenata korelacije pojedinog parametra izračunat je postotni udio te vrijednosti u odnosu na ukupnu vrijednosti svih parametara. Izračunat postotni udio veze poslužio je kao postotni udio te varijable u funkciji preklapanja udjela u modelu zaštitnog potencijala reljefa. Veza je temeljena na činjenici da jakost veze pojedinog parametra u odnosu na ostale ima direktan odraz na ukupan rezultat, te će parametri sa

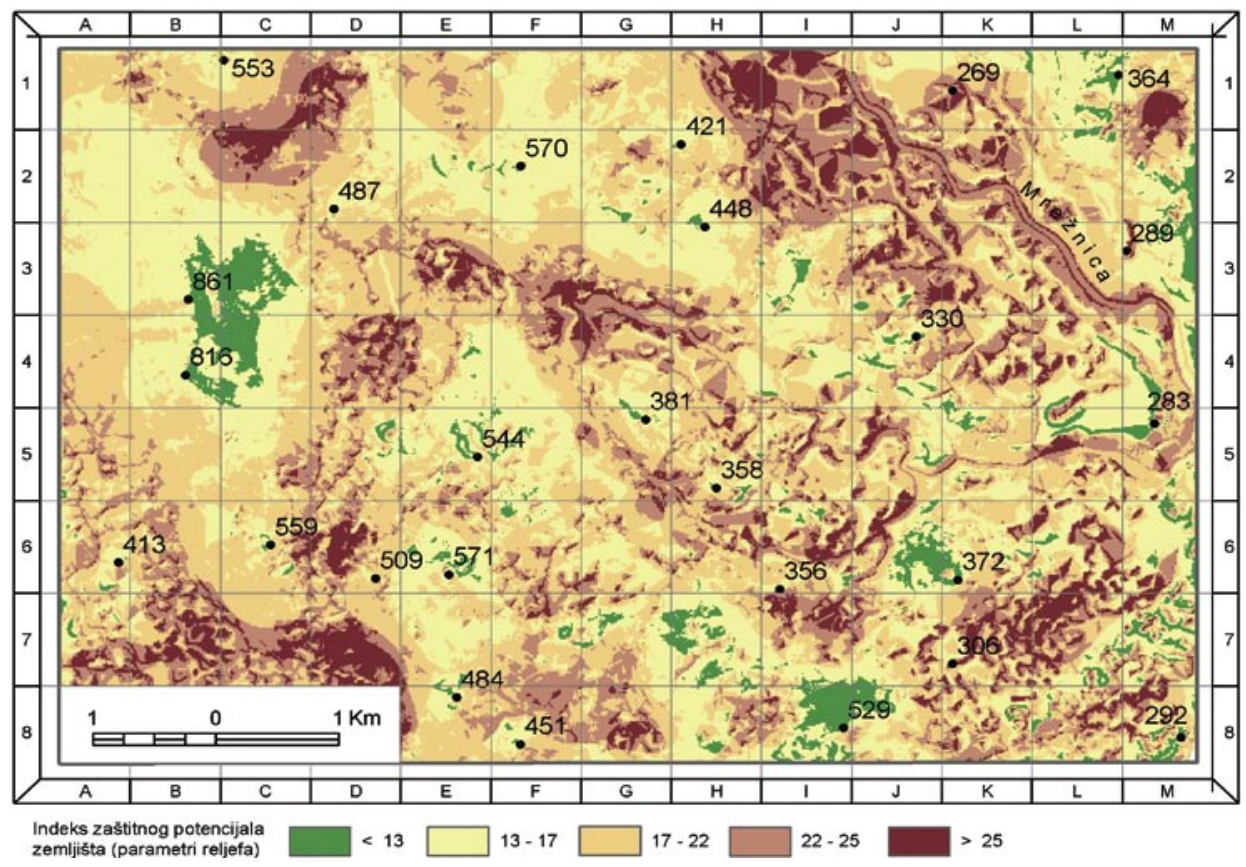

S1. 9. Vrijednosti Indeksa zaštitnog potencijala reljefa

Fig. 9. Values of the Relief protection potential index 
Mladen Pahernik, Darko Kereša - Primjena geomorfoloških istraživanja u vojnoj analizi terena - indeks zaštitnog potencijala reljefa

Tablica 3. Postotni udjeli klasa indeksa zaštitnog potencijala reljefa unutar istraživanog područja

\begin{tabular}{|c|c|c|c|}
\hline $\begin{array}{l}\text { Indeks zaštitnog potencijala } \\
\text { zemljišta (parametri reljefa) }\end{array}$ & Opis klase & Zaštita & $\begin{array}{c}\text { Udio postotka } \\
\text { površine }\end{array}$ \\
\hline$<13$ & Izrazito otvoren prostor & Izrazito nepovoljna & 4,1 \\
\hline $13-17$ & Otvoren prostor & Nepovoljna & 30,3 \\
\hline $17-22$ & Zaštićen prostor & Dobra & 38,5 \\
\hline $22-25$ & Dobro zaštićen prostor & Povoljna & 18,7 \\
\hline$>25$ & Izrazito zaštićen prostor & Izrazito povoljna & 8,4 \\
\hline
\end{tabular}

jačom korelacijskom vezom prema drugim parametrima u odnosu na promatranu pojavu, proporcionalno utjecati i na intenzitet vrijednosti rezultata. Metodom preklapanja udjela zbrojene su vrijednosti svake ćelije pojedinog parametara GRID-a pomnožene sa koeficijentom postotnog udjela definiranog temeljem korelacijske matrice međusobnih vrijednosti koeficijenta korelacije svih parametra analize. Izračunate vrijednosti indeksa zaštitnog potencijala zemljišta s obzirom na parametre reljefa (Sl. 9) definirane su kroz pet klasa mogućnosti zaštite i prikrivanja (Tab. 3).

\section{ZAKLJUČAK}

Primjena modela indeksa zaštitnog potencijala reljefa u analizi SI dijela vojnog poligona «Slunj» ima za cilj definirati temeljne zaštitne mogućnosti reljefa s obzirom na mogućnost zaštite od motrenja, te zaštitu od učinka izravne protivničke paljbe. Gledajući istraživani prostor kao cjelinu potencijalnog bojišta iz provedene analize proizlazi da ukupno 65,6 \% površine zadovoljava (zaštićen, dobro zaštićen i izrazito zaštićen prostor), a tek $34,4 \%$ ne zadovoljava (izrazito otvoren i otvoren prostor) uvjetima povoljnog zaklanjanja i prikrivanja s obzirom na reljefne čimbenike. To govori u prilog činjenici da je analizirano zemljište povoljnije za provedbu napadnih djelovanja jer veći dio terena omogućuje relativno prikriveni manevar postrojbi u napadnim djelovanjima. Posljedica je to veće reljefne dinamike u okružju gorskih masiva i pobrđa koji dominiraju unutar istraživanog prostora. Iz prikaza indeksa zaštitnog potencijala reljefa uočava se jasna podjela između uzvišenih, otvorenih prostora gorskih uzvišenja, kao generalno nepovoljnih reljefnih oblika zaštite, te konkavnih kao generalno povoljnih reljefnih oblika zaštite. Na temelju vrijednost indeksa zaštitnog potencijala reljefa mogu se unutar spomenutih reljefnih oblika diferencirati pojedini reljefni elementi (padine, grebeni, vrhovi) na izrazito povoljne, odnosno povoljne, te izrazito nepovoljne i nepovoljne. Time se dobila mogućnost primjene opisane metode, ovisno o točnosti i preciznosti ulaznih parametara, i na taktičkoj razini. Daljnjom analizom dobivenih vrijednosti indeksa zaštitnog potencijala reljefa sa ostalim vrijednostima analize zemljišta, pri čemu se prvenstveno misli na analizu mobilnosti, moguće je definirati karte općeg utjecaja reljefa na borbena djelovanja. Primjena tih podataka veže se za analizu širih vojnih operacijskih smjerova, jasno uz generalizaciju ulaznih parametara.

Digitalna analiza reljefa, primjenom algoritama GIS prostorne analize, omogućila je kvalitetnu analizu geomorfoloških parametara u funkciji računanja zaštitnog potencijala reljefa. Zamjenom klasičnih analognih izvora podataka digitalnim, temeljenih prvenstveno 
na digitalnom modelu reljefa, s primjenom algoritama za računanje pojedinih parametara geomorfološke analize, ubrzan je sam proces određivanja pojedinih kvantitativnih parametara reljefa. To se prvenstveno odražava prilikom analize reljefa većih područja, odnosno prilikom razvoja metoda za dobivanje parametara koji nisu relevantnom kvantitativnom metodom mogli biti određeni temeljem analognih izvora, odnosno dobivani su generalizacijom unutar šireg prostora. Za potpunu primjenu modela potrebno je definirati i ostale atribute zaštitnog potencijala reljefa vezane za vegetacijska i antropogena obilježja zemljišta.

\section{ZAHVALA}

Prikazani rezultati proizašli su iz znanstvenih projekata: "Geomorfološko kartiranje Republike Hrvatske» $i$ «Geomorfološka i geoekološka istraživanja krša Republike Hrvatske» uz potporu Ministarstva znanosti Republike Hrvatske.

\section{POZIVNE BILJEŠKE}

1. Metoda reklasifikacije uključuje dodjeljivanje jednoznačnog boniteta definiranom rasponu vrijednosti pojave. Tako npr. sve ćelije rasterskog modela podataka gustoće ponikava u rasponu vrijednosti manjoj od 10 ponikava $\mathrm{km}^{2}$ dobivaju novu bonitetnu vrijednost 0 , zatim u rasponu vrijednosti od $10-40$ ponikava $\mathrm{km}^{2}$ vrijednost 0,5 itd.

\section{LITERATURA}

Ahlvin, R.B., and Haley, P.W. (1992): NATO reference mobility model edition II, NRMM II user's guide, Technical Report GL-92-19, U.S. Army Engineer Waterways Experiment Station, Vicksburg.

Bognar, A. (2001): Geomorfološka regionalizacija Hrvatske, Acta Geograph. Croatica 34, Zagreb, 7 - 29.

Birkel, P. A., (2003): Terrain Trafficability in Modeling and Simulation, Sedris - Technical Paper 2003- 1, 40 pp.

Cesur, F. (2005): Optimizing Formation Movement Over Heterogeneous Terrain, Master's thesis, Naval Postgraduate School, Monterey, 59pp.

Friend,A(2005): Environmental Analysis in Support of the Military Commander, Sixth International Conference on Military Geology and Geography, June 2005, Nottingham

Grindle, C., Lewis, M., Glinton, R., Giampapa, J., Owens, S. and Sycara, Katia (2004): Automating Terrain Analysis: Algorithms for Intelligence Preparation of the Battefield, Proceedings of the Human Factors and Ergonomics Society, $533-537$.

Guth, P. (2005): Challenges for Military Application of High Resolution DEMs, Sixth International Conference on Military Geology and Geography, June 2005, Nottingham 
Mladen Pahernik, Darko Kereša - Primjena geomorfoloških istraživanja u vojnoj analizi terena - indeks zaštitnog potencijala reljefa

Gilewitc, D, A (2003): Military Geography: The Interaction of Desert Geomorphology and Military Operations, Doctoral thesis, Arizona State Univ. Tempe., 313 pp.

Jenson S. K. and J. O. Domingue, (1988): Extracting Topographic Structure from Digital Elevation Data for Geographic Information System Analysis, Photogrammetric Engineering and Remote Sensing. Vol. 54, No. $11,1593-1600$ pp.

Johnson, C. and Smith, J. (1983): Soil loss caused by off-road vehicle use on steep slopes. Transactions of the ASAE 26(2), 402-405 pp.

Pahernik, M. (2005): Geomorfološka obilježja Gorskog kotara, primjena GIS-a u istraživanju reljefa, Disertacija. Geografski odsjek PMF-a Sveučilišta u Zagrebu, 378.

Patricia, M., Sullivan, P. and Anderson, A., (2000): A Methodology for Estimating Army Training and Testing Area Carrying Capacity Vehicle Severity Factors and Local Conditions Factors, US Army, ERDC, TR-00-2, Vicksburg, $45 \mathrm{pp}$.

Salomon, B., Govindaraju, N., Sud, A., Gayle, R., Lin, M., Manocha, D., Butler; B., Bauer, M., Rodriguez, A., Eifert, L., Rubel, A., Macedonia, M. (2004): Accelerating Line of Sight Computation Using Graphics Processing Units, 24th Army Science Conference Proceedings, Orlando, 8 pp.

Silverman, B.W. (1986): Density Estimation for Statistics and Data Analysis. New York: Chapman and Hall. 